\title{
Voters Orientation Starter Set Toba Batak Ethnic Background (Case Study In Tiga Balata Simalungun)
}

\author{
1Gomgom Manurung, ${ }^{2}$ Robert Sibarani, ${ }^{3}$ Erond Damanik \\ 1State University of Medan \\ 2University of Nourth Sumatera \\ ${ }^{3}$ State University of Medan \\ Medan, Indonesia
}

\begin{abstract}
The existence of voters always promising in terms of quantity. Political orientation of voters is always dynamic and will change following the existing conditions and the factors that influence it. On elections in three Balata later, it is likely the number of voters who Toba Batak tribes reached more than $10 \%$ of the total number of voters starters who entered the final voters list (DPT). In determining The choice, voters would not be separated from the preferences given by the social groups around them. This study aims to determine how the participation of voters are ethnic Batak Toba in choosing the Simalungun area. Through this approach then described how social groups are formed due to the social groupings in the community provide political preference to voters. This research use descriptive research type with qualitative methods. The data obtained in this study comes from indepth interviews and documentation study. Informants selected by purposive sampling, which is derived from the existing voters and domiciled in Tiga Balata or Simalungun area. The results of this study found the data and the fact that the social groups formed for their grouping in society is not fully formed political behavior and give preference to voters in determining their political choice on the election in Tiga Balata later. In determining the choice, voters Batak Toba Tiga Balata be put assessment of the figure and the personality and attitude that is shown each candidate as the primary assessment.
\end{abstract}

Keywords: Orientation Voters, Social Groups, Beginner Voter Behavior Batak Toba

\section{INTRODUCTION}

Elections are an important part of democracy. Election, if defined simply is the way individual citizens engage in political activity or political contracts with others or political parties given the mandate or authority to exercise some of the power of the people / voters. Elections are not a total mandate of power. The claim of a political party stating that his party has had voters with a certain total amount in the election is not appropriate. To carry out the mandate political parties or executives of political parties must make political communication in determining the policies for the interests of the people with the consent of the citizens.

Beginner voters in the political category are the first group to exercise their right to vote. In using his political suffrage, following the typology of the Almond and Verba model (1990: 16), the beginner's political orientation is categorized into, (1) cognitive orientation, knowledge of and trust in the candidate, (2) effective political orientation, election, the influence of friends on the determination of choice, and (3) evaluative political orientation, namely the decision and opinion of the novice voters to the political party / candidate of his choice. The political orientation of novice voters is always dynamic and will change according to the conditions and the factors that influence it.

Political orientation is actually a way of looking at a society in a social structure. The emergence of orientation is based on the values that exist in society and from outside the community that then forms the attitude and become their pattern to look at a political object. It is the political orientation that then forms the order in which these emerging interactions ultimately affect a person's political behavior. This political orientation can be influenced by the individual's orientation in view of political objects. The object of political orientation involves one's involvement in: (1) the system as a whole and includes certain feelings such as patriotism and alliance, cognition and evaluation of a nation, and (2) the person as a political actor, content and quality, norms of political obligation someone. A person's political orientation will encourage political participation. Including what happens with the political orientation of newbie voters in the election in Tiga Balata later.

In this paper, the authors intend to describe what factors affect the early voters who have ethnic background in using their voting rights in Tiga Balata later ?, which factor is the most dominant in influencing the beginner voters using their voting rights in the election in Tiga 
Balata later? What is the political orientation of early voters with ethnic background in exercising their voting right in Elections in Tiga Balata Later?.

\section{METHODOLOGY}

This research uses qualitative approach supported by quantitative data. Research that produces descriptive data in the form of written or oral words and behavior of the observable people (Moleong, 1990:3).

The location of this research is Three Balata. The researchers chose Tiga Balata as the location of the research on the grounds that in the Tiga Balata will be held Selection with a large number of beginner voters with a high plurality / heterogeneity and a complex orientation and voters or people living in Tiga Balata have different ethnicities.

The focus of this research is to examine the variables on (1) factors affecting different tapered voter groups using their voting rights in the Elections in Tiga Balata, (2) the dominant factors in influencing the novice voters using their voting right in the next election, and (3) The political orientation of newbie voters in exercising their voting right in the Elections in the Tiga Balata later.

\section{RESULT AND DISCUSSION}

Based on the data collection in the field of interviews with 50 respondents consisting of third-grade students and students who are beginner voters, the researchers found the factors that influence beginner voters in using their voting rights in the election in Tiga Balata are:
Table: Factors that affect the novice selector in exercising his / her right to vote

\begin{tabular}{|c|l|c|c|}
\hline No & $\begin{array}{c}\text { Factor } \\
\text { affecting }\end{array}$ & Respondents & Percentage \\
\hline 1 & Parents & 16 & 32 \\
\hline 2 & Own Choice & 20 & 40 \\
\hline 3 & $\begin{array}{l}\text { Political } \\
\text { Parties, } \\
\text { Mass Media } \\
\text { and } \\
\text { Political } \\
\text { Advertising }\end{array}$ & 9 & 18 \\
\hline 4 & Friends & 5 & 10 \\
\hline & Amount & 50 & 100 \\
\hline
\end{tabular}

From the table above, the dominant factor that influenced the beginner voters using their voting right is $40 \%$ own choice factor, then the parent factor $32 \%$.

Political orientation is actually a way of looking at a society in a social structure. The emergence of the orientation is motivated by the values that exist in society and from outside the community which then form the attitude and become their pattern to look at a political object. Based on data collection field, and then in this study found that the political orientation of newbie voters in using the right to vote on the election in Tiga Balata:

1) Cognitive Orientation, that is knowledge about and trust of mayor candidate. At this level of cognitive orientation it is found that

a. Eleven (11) people (22\%) stated that they did not recognize the candidate pairs in the election in Tiga Balata later and did not know the vision of his mission. They know the names of the candidate pairs when they are at the Voting Place (TPS) on Day $\mathrm{H}$ or when they will vote on the ballot.

b. Twenty (20) people (40\%) state that they know the candidate but are unaware of their vision and mission. They know the names of candidate pairs through banners and billboards, political ads on TV, and conversations with friends or parents. 
c. Nineteen (19) people (38\%) stated that they knew the candidates and their visions. They know the names of the candidate pairs and their mission vision from through mass media, candidate campaigns, political advertisements in parties, and leaflets.

Based on the description above, this orientation has led to a positive orientation where the level of knowledge of novice voters is quite high on the name and vision of the candidate's mission in the election in Tiga Balata

2) Affective orientation, ie feeling towards the implementation of Mayor Election Semarang 2010. At this level of orientation, based on the interview results found the fact that in choosing beginners determine the choice of candidates in the election, influenced by factors, among others, parents factor 32\%, factor $40 \%$ own choice, Political Parties, Mass Media and Political Advertising 18\%, peers $10 \%$. This situation indicates a positive orientation, that is, the orientation shown by a high decision-making rate of $40 \%$ is based on the choice of inner voters in the election in Tiga Balata.

3) Evaluative Orientation, namely the decision and opinion of the novice voters to the candidate pair in the election in Tiga Balata

Political behavior is generally determined by the internal factors of the individual himself such as idealism, intelligence level, and the will of the heart and by external factors (environmental conditions) such as religious life, social, political, economic and so on that surrounds it. Political behavior is a behavior that concerns the issue of politic to regulate people's lives toward that achievement. Political behavior is an act done by a subject that can be a government as well as a society.

In the context of political behavior, the thing that is thought and desired is closely related to the political orientation of the power in which power is obtained by a process of election. Although theoretically, the explanation of the behavior that arises from differences in attitude is obvious, but attitude is not something that can just happen. Attitudes formed from a long socialization process, from newborn to adult. Through this process of socialization and then develop a strong psychological bond between a person with community organizations or political parties in the form of sympathy.
Political orientation is actually a way of looking at a society in a society structure. The emergence of the orientation is motivated by the values that exist in society as well as from outside the community that then form an attitude and become their pattern to look at a political object.

The results of research on factors that determine or influence political participation in using the right to vote, among others. First, the parents factor. This factor has considerable influence affecting novice voters in exercising their voting rights. Based on these interviews it is known that 16 respondents from 50 respondents $(32 \%)$ stated they were using their voting right to follow the parents. Second, the choice factor itself. This factor has a great influence on the novice voters in exercising their voting rights. Based on the results of data collection in the field of 20 respondents from 50 (40\%) of respondents stated that they chose because of their own choice without being affected by others. Third, the factors of political parties, political advertising and mass media. This factor has little influence in influencing voters using their rights, and Fourth, the factor of peers. This factor has a level of affecting beginner voters in exercising their lowest voting rights. This result when we associate with theories that influence the political participation of students as novice voters is not contradictory.

Factors influencing the political participation of students as novice voters are as follows: (1) socio-economic factors, including income level, education level and number of students. This has become a factor in influencing students as novice voters to participate actively in politics; (2) political factors, including: (a) Political communication is a communication that has political consequences both actual and potential, which regulate human behavior in the existence of a conflict, (b) political awareness, which concerns the knowledge, interest and attention of a person to the community environment and the political knowledge of the students as a novice voter to the decision-making process; and (c) the knowledge of the students as a novice voter on the decision-making process will determine the style and direction of a decision to be taken; (3) individual and environmental physical factors, as a source of life including facilities and the availability of public services; and (4) the cultural value factor that forms the basis for democracy, concerning perceptions, knowledge, attitudes, and political beliefs.

In the behavioral approach, there is interaction between humans with each other and 
will always be associated with knowledge, attitudes and values of a person who then raises the orientation so that the behavior arises. It is the political orientation that then forms the order in which these emerging interactions ultimately affect a person's political behavior. The classification of the types of political orientation is (1) the cognitive orientation, the knowledge of and belief in politics, the role and all its obligations and its inputs and outputs, (2) the effective orientation, the feeling toward the political system, the role, the existence of the actor and his appearance, (3) evaluative orientation, decisions and opinions on political objects that typically involve a combination of standard values and criteria with information and feelings.

One's orientation to political objects can be classified as follows. (1) Positive Orientation, which is orientation shown by high level of knowledge and frequency of consciousness, positive feelings and evaluation of political objects, (2) Negative Orientation, ie orientation shown by low level of knowledge and frequency of awareness, evaluation and negative feelings (3) Neutral Orientation, which is the orientation shown by the frequency of high indifference or has a very limited orientation level or even no orientation at all to political objects. The political orientation of novice voters based on this research shows toward a positive orientation in cognitive, affective and evaluative orientations. This shows the orientation shown by the high level of knowledge and frequency of consciousness, positive feelings and evaluation of political objects.

\section{CONCLUSION}

Based on the results of data collection in the field and the results of research in the previous chapter, the researcher concludes: (1) the factors that influence the novice voters in using their voting right in the election of Mayor of Semarang 2010 is the influence factor of parents, the factors of choice, mass media factor, (2) dominant factors affecting beginner voters in exercising their voting rights in the election in the Three Balata are influencing factors of self-choice $(40 \%)$ and parents (32\%), and (3) the political orientation of newbie voters in the exercise of their voting rights in the election, including cognitive, affective and evaluative orientations has led to a positive orientation where the orientation is indicated by a high level of knowledge and frequency of consciousness, positive feelings and evaluation of political objects.
Based on the results of the conclusions, the researcher suggests that (1) To improve the political orientation of beginner voters, it is necessary to do political education for beginner voters through formal, informal and non-formal activities, (2) Election Commission in Tiga Balata in conducting more intensive regional head election in conducting socialization by conducting counseling, simulating "mencontreng", the introduction of profiles of candidates, especially on novice voters who have different ethnic or ethnic groups.

\section{ACKNOWLEDGMENT}

The authors would like to thank the graduate program of Medan State University, especially the lecturers of Post-Graduate of Social Anthropology, who provide opportunities to gain knowledge and facilitate the formation of this paper

\section{REFERENCES}

[1] Almond. A Gabrriel dan Verba. 1990. Budaya Politik Tingkah laku Politik dan Demokrasi di Lima Negara. Jakarta: Bumi Aksara.

[2] Budiyanto. 2000. Dasar-Dasar Ilmu Tata Negara. Jakarta: Erlangga.

[3] Budiarjo, Miriam. 2003. Dasar-Dasar Ilmu politik. Jakarta: PT Gramedia Pustaka Utama.

[4] Gatara, Said. 2007. Sosiologi Politik, Konsep dan Dinamika Perkembangan Kajian. Bandung: CV Pustaka Setia.

[5] Moleong, Lexy j. 1997. Metodologi Penelitian Kualitatif. Jakarta: Roesdakarya.

[6] Ruslan, Ustman Abdul Muiz. 2000. Pendidikan Politik Ikhwanul Muslimin. Solo: Era Intermedia

[7] Surbakti, Ramlan. 1999. Memahami Ilmu Politik. Jakarta: PT. Grasindo. 